\title{
1
}

\section{Why and How to Study Trade Union Cooperation in Europe?}

\begin{abstract}
This chapter gives a general background to the issue of transnational union cooperation in Europe and presents the aim, outline and delimitations of the book. It also pays attention to a number of concepts that can be relevant in the analysis of European trade unions and industrial relations. In this way, a theoretical context is provided for the analyses to come. There is moreover a rather detailed description of the empirical materials and methods used in the following chapters.
\end{abstract}

Keywords Transnational trade union cooperation - Industrial relations . Data collection methods

\section{Introduction}

Against the background of a gradually widening and deepening European integration process, transnational trade union cooperation is of great importance for workers. The trade union movement has traditionally a strong position in Europe compared to other regions of the world, but this strength is largely rooted in national industrial relations institutions. The increasing integration and enlargement of the European internal market have created challenges for labour organizations to enhance 
their cross-border coordination and collaboration, not to be marginalized in terms of influence when safeguarding the interests of their members (Erne 2008; Gajewska 2009; Gumbrell-McCormick and Hyman 2013; Seeliger 2019).

A problem in this connection is that national unions in Europe are experiencing setbacks due to declining membership numbers ('union density') and decreasing power resources (Kelly 2015; Lehndorff et al. 2017). This is partly related to the EU integration process, for example when the scope of action for unions at national level was reduced by the European Court of Justice's decisions in a series of notable judgements in the early 2000s, in particular the so-called Laval Quartet of rulings (Bücker and Warneck 2010). Moreover, in the aftermath of the economic crisis starting in 2008, the increased transnational governance of the Euro-zone countries within the EU brought widespread social consequences for workers. Parts of the austerity policy following the crisis led to a weakening of trade unions' power and negotiating opportunities in some countries, adding to the already existing pressures towards neoliberalization and decentralization of collective bargaining at national level (Baccaro and Howell 2017; Marginson 2015).

The EU is sometimes depicted as a liberal market project, driven by 'negative integration', which means that the main project is to remove barriers to the free movement of goods, services, labour and capital (Scharpf 1996). However, there have also been many discussions and initiatives over the years to introduce and strengthen elements of 'positive integration', for example by shaping common identities, rights and conditions for citizens in Member States (Rhodes 2015). These ambitions are often referred to as the European 'social dimension' or even as 'social Europe' (Seeliger 2019: 28-31). One quite recent example is the European Pillar of Social Rights with its chapters setting up principles concerning 'Equal opportunities and access to the labour market'; 'Fair working conditions' and 'Social protection and inclusion' (European Commission 2017).

Cooperation between trade unions in Europe is actually since long supported and institutionalized by the European Commission as an integrated part of the EU multilevel governance system. The Commission 
has facilitated structures for unions and employer associations to participate in both consultations on EU policies and social dialogue. This offers possibilities of negotiating agreements that can be turned into directives (Rhodes 2015). Even though lately questioned by some unions and researchers (Tricart 2019), the Commission has repeatedly emphasized the importance of European-level social dialogue between trade unions and employer organizations for EU governance:

Developing and fostering social dialogue is an essential element of the European social model, as it plays a crucial role in promoting competitiveness and fairness and enhancing economic prosperity and social well-being. European social dialogue complements the social dialogue happening at the national level. (European Commission 2016: 3)

Historically, the EU social dimension has been very much about employment and working life issues. To realize the European social model, a crucial condition is that the labour organizations are able to take an active role in safeguarding and advancing measures in the intended direction. If they are to do so, they must be able to cooperate effectively across national borders. This is especially difficult as union power is declining at national level in many countries, while simultaneously many important decisions are made in multinational companies and a lot of politics has moved beyond the national arena.

\section{Aim and Outline of the Book}

This book aims to provide an analysis of transnational trade union cooperation in Europe-its forms and focuses and its conditions and obstacles. It is not only a study of union cooperation as such, but also illustrates the interconnections between national and European industrial relations. Thereby it gives examples of the workings of the European integration process in the labour markets, and particularly of the potential and difficulties in developing and deepening the social dimension.

There are of course a number of limitations when we approach such broad issues in a narrow format; of course, not everything of relevance 
can be covered. As economic and political conditions change fast both nationally and in the EU, we have to hit a moving target in our analyses. Our empirical attention is mainly directed to cooperation between unions at sectoral and cross-sectoral level. Therefore we have less to say about the European structures of workers' collaboration at company level, established in the form of European Works Councils (EWCs), important as they may be. For this level of union cooperation, the reader has to search for other scholarly overviews (e.g., Hann et al. 2017; Whittall et al. 2007).

Since our focus is on trade union cooperation, we provide few details about the employer side and the European institutions as well as about the interaction between these two and the unions, possibly with some exception of Chapter 4. As we use broader scholarly research to place union collaboration within the context of European industrial relations, at least some anchor points are supplied for our analyses. The role of EU institutions as facilitators and driving forces of union cooperation has been covered in many useful overviews, on which we will lean (e.g., Rhodes 2015; Smismans 2012; Welz 2008). With respect to the employer side, there seem to be fewer studies, but there are quite a number of valuable overviews of the interactions between employers and trade unions in European-level social dialogues (e.g., Keller and Weber 2011; Perin and Léonard 2011; Prosser 2016; Tricart 2019).

Besides presenting the background and the aim of the book, this introductory chapter has two major subsections. The first introduces some main theoretical concepts and discusses different approaches to the study of European industrial relations. One strand is the comparative approach, which is usually about making comparisons between countries, between industrial relations regimes, or between sectors. Another dimension is the existence of a supranational European level, which can be scrutinized in terms of actors, institutions, interactions and outcomes. The current chapter ends with a description of the empirical materials used in the analyses in the book.

Chapter 2 gives an overview of the patterns of cross-border union cooperation based on our empirical studies. We begin with a brief discussion of the multilevel structures that exist in such collaboration and 
continue by presenting trade unions' views on the importance of working together at different levels and on the potential benefits to be gained through this. In the second section, we go into a more detailed discussion about what topics and themes that are important in transnational union cooperation and what forms of cooperation that are preferred in different sectors and industrial relations regimes. The last parts of Chapter 2 examine the most important obstacles and facilitators to union collaboration in Europe.

Then, in Chapter 3, we move to a more detailed analysis of an issue of great importance for trade unions: statutory minimum wages. It is a case study of union views regarding minimum wage legislation at national and European levels. After providing some basic information on such regulation in Europe, the analysis concentrates on different arguments for and against it. Empirical data, from surveys as well as from interviews and documents, are used to describe the positions taken by labour organizations. There is a deep cleavage on the topic in the European union movement and the resistance to legislation is strongest in the Nordic countries, whereas the opinion is much more positive in most other parts of Europe. The European Trade Unions Confederation (ETUC)-the unions' large cooperation organization in Europe-has thus had certain difficulties to deal with, but it has been able to find a compromise that its members can tolerate. Still, importantly, the issue of statutory minimum wages is not something that all European labour organizations can presently be expected to collaborate on.

Chapter 4 contains an analysis of another potentially divisive issue in trade union cooperation: the revision of the Posting of Workers Directive (PWD) which can be seen in light of the discussion on 'social dumping'. In 2016, the European Commission proposed a revision of the PWD and it led to a great deal of debate, with a clear East-West division in the reactions. The proposal aimed at eliminating certain kinds of social dumping; the goal was that the same work in the same place should get the same pay. Ministers and parliaments in several Central/Eastern European countries raised their voice against the revision. Employers' organizations were generally negative, while the trade union confederations at European level were positive but not uncritical as they wanted a more radical reform. No manifest East-West cleavage became visible in the 
trade union movement. Even in countries dismissive of the revision, the main labour organizations supported the dominant union responses.

In the concluding Chapter 5, we summarize the results presented in our analyses and revisit some of the contextual and theoretical discussion from the introductory chapter. The purpose of this is to draw some general conclusions regarding the importance of understanding trade union cooperation as dependent on organizational and other power resources and the varieties of industrial relations and sectoral regimes across Europe.

\section{Trade Unions and Industrial Relations in Europe}

A trade union may be defined as 'a continuous association of wage-earners for the purpose of maintaining or improving the conditions of their employment' (Webb and Webb 1894: 1). By organizing in associations, workers can avoid underbidding each other in the labour market and they can defend or improve joint standards for employment and working conditions, either directly in collective bargaining with the employers or indirectly by influencing state regulations. The establishment of trade unions and collective bargaining institutions can also be beneficial to employer organizations and national governments, since they may help to 'maintain social peace and ensure the legitimacy of managerial control' (Traxler 1998: 208).

The aim and function of unions in the labour market and in society can ideal-typically be depicted as threefold, and the balance between these three aspects varies by tradition across Europe (Hyman 2001b). From a labour market point of view, trade unions (and employer organizations) may be seen as economic cartels negotiating the price of work and employment conditions. According to this approach, the organizations mainly defend the interests of their members, who may be employees in a specific company, in certain occupations, or in a specific sector of the economy. From a political point of view, unions may be regarded as social movements aimed at resource mobilization for the working class in general to influence state regulations of employment and working conditions 
or even to address more universal issues concerning wealth and welfare. The solidarity of unions in this approach extends far beyond their members. The third aim and function of trade unions can be said to relate to overall social cohesion. They are then seen as civil society organizations bridging the contradiction between labour and capital in 'social partnership', dialogue and compromise (Hyman 2001b: 38-63). This approach is thus less related to antagonistic relations and conflict, but rather to overall 'social responsibilities' of the organizations. Unions are assumed to cooperate with employers and the state for the overall good for workers and companies in a certain sector of the economy or social cohesion at large.

Trade unions may have different power resources linked to these aims and functions (Gumbrell-McCormick and Hyman 2013: 30-35; Lehndorff et al. 2017). Their organizational power is based on their number of members, who through membership fees may build up financial and staffing resources. Unions below the confederate level may range from a few hundred or a few thousand members to millions of members, as in the German services union Ver.di. This of course affects their possibilities of financing and staffing various operations as well as mobilizing members in action. Still, the most important may not be whether a trade union has a large number of members, but whether or not it organizes a large proportion of the employees. Just to give a sense of such differences we can mention that overall union density in Europe varies from around 4.5\% in Estonia to above 90\% in Iceland (Visser 2019). Another dimension is structural power that is close to organizational power, but is more about the bargaining strength of unions versus employers - in their company, occupation, sector or the economy at large. This kind of strength is also a function of unemployment levels and employers' demand for labour. A third component is unions' institutional power that has to do with their legal (institutionalized) rights to organize, be consulted, bargain, have their agreements legally extended and take industrial action. Unions' societal power, finally, is based on their ability to build alliances with political or civil society organizations and influence public discourse. All these forms of power differ substantially across countries and at the same time it must be stressed that they are not independent of each other. 
The concept of industrial relations broadly refers to /i/nteraction between employers, employees, and the government; and the institutions and associations through which such interactions are mediated' (Brown et al. 2018; italics added). The three italicized aspects of industrial relations were already emphasized when the concept was theoretically elaborated for analyses at national level, that is, rules, collective action, bargaining and power relations were in focus (Dunlop 1958). By emphasizing one of them above the others, we may actually talk about three different approaches to industrial relations. A strong focus on the associations - trade unions, employer organizations and the government and their collective interests and power resources-leans towards political economy and Marxist conflict-oriented traditions. If instead concentrating on the relations and interactions between the collective actors-through social dialogue, bargaining, lobbying or contentious action such as demonstration strikes, blockades and lockouts-there is a turn towards more of a strategic action perspective (Hyman 2001a: 5). Lastly, a concentration on the institutional aspect of industrial relations-for example the regulative, normative and cultural-cognitive frames in which the collective actors and their interactions are embedded and reproduced (Godard 2004) — tends towards a sociological or organizational neo-institutionalist approach. In this case, there is inspiration from older theories based on functionalist reasoning. As we see it, the differences between these views are not so much an issue of what is fundamental in an ontological sense, since frequently in research all three aspects exist and are mutually interdependent. This can be illustrated by the definition of industrial relations as institutional arrangements shaped by legislative frameworks, historical traditions, accumulated vested interests and learned patterns of behaviour' (Hyman 1994: 1).

Even if the concept of industrial relations was originally developed to study the institutionalized interactions between employers and employees within nation states, it is today often used in comparative and even transnational analyses. There are at least three different approaches to such studies and we will now briefly discuss these in turn. 


\section{Comparisons of Industrial Relations in Europe}

The most direct way to study European industrial relations is to compare national industrial relations across countries. Such an approach commonly focuses on structural factors. The main ones used are trade union and employer membership, the organizations' power resources and the power balance between them, local employee representation, collective bargaining styles and coverage, levels of coordination or centralization of bargaining, the social partners' political influence and the role of the state (e.g., Baccaro and Howell 2017; Visser et al. 2009; Henning 2015).

In dealing with a large number of countries, such comparisons run the risk of getting quite messy. Thus, some selection of a smaller set of countries is often needed in order to produce and present results in digestible form. One possibility is that the selection is made on the basis of a 'varieties-of-capitalism' perspective (Baccaro and Howell 2017; Bamber et al. 2016; Seeliger 2019). Another approach, which is commonly applied in research including European and international comparisons, is to cluster countries on the basis of similarities into a smaller set of regimes of industrial relations (Visser et al. 2009; Eurofound 2017) or varieties or models of trade unionism (Gumbrell-McCormick and Hyman 2013: 6-28; Hyman 2001b; Lehndorff et al. 2017).

Without a doubt these attempts to reduce variation have significant advantages, but they can also have disadvantages, by reducing the existing diversity too much. Anyway, we will try them out to test their explanatory power. We will soon discover their limitations, for example in connection with specific problematic topics in union cooperation, such as the question of statutory minimum wages to be dealt with in Chapter 3 .

Empirically grounded typologies of European countries with a smaller set of regimes or models of trade unionism — or welfare regimes, varieties of capitalism, or employment regimes for that matter-generally tend to single out the same geographic clusters of countries. We use the regional terms Central/Eastern Europe, Central/Western Europe, Nordic region, Southern Europe and Western Europe. Some central characteristics of the regimes in these clusters are presented in Table 1.1 and will be elaborated briefly. 


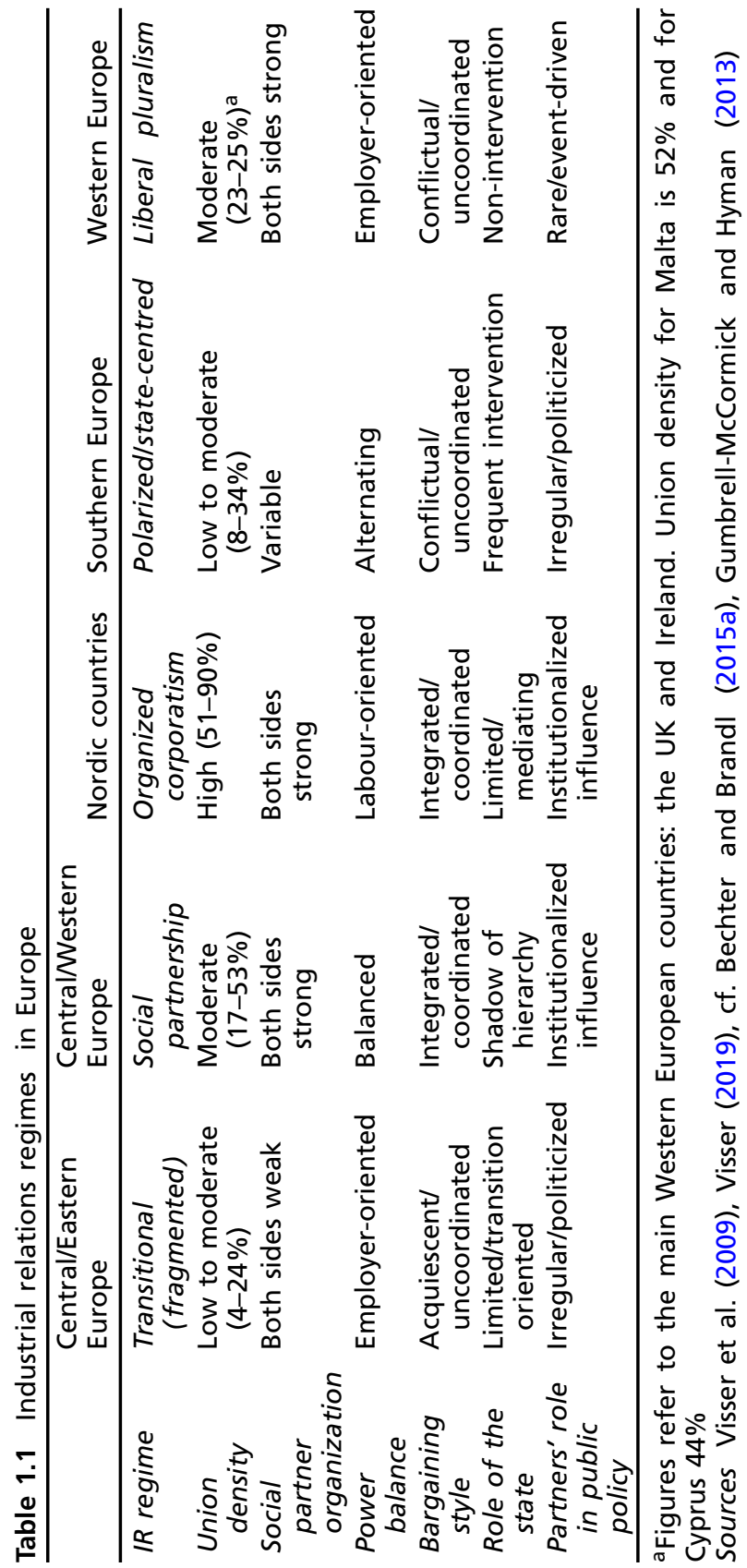


The many Central/Eastern European countries are quite diverse and it may be questioned whether they make up a regime at all. As we can see in Table 1.1, they are classified as belonging to a transitional or fragmented regime of industrial relations. The term transitional refers to the changes from the previous state socialist systems to liberal market economies, while 'fragmented' signals both the variation between countries and the social partners' generally low degree of organization and coordination within countries. Trade unions are quite weak in most of these nations, union density is generally low and workers usually do not identify that strongly with unions, partly because of their history. The tradition of contentious action is weak, and several countries have clear restrictions on the right to strike. Bargaining is mostly decentralized to the company level, and even though national confederations exist, in many countries the sectoral level is undeveloped. The social partners have relatively little bargaining autonomy, as governments frequently have been more concerned with the transition to a market economy than with regulating labour relations (e.g., Bieler and Schulten 2008; Henning 2015; Visser et al. 2009).

The Central/Western European countries Austria, Belgium, Germany, Luxembourg, the Netherlands and Switzerland are described as having a social partnership tradition (Bieler and Schulten 2008; Visser et al. 2009). Slovenia was later added to this category. In these countries, there are developed tripartite and corporatist relations between trade unions, employers and the state. They are thus said to belong to a social partnership regime of industrial relations. The social partners have a high degree of autonomy from the state, collective bargaining coverage is generally high because of legal extension mechanisms, and unions' political influence is fairly strong. Union density is moderate, although much higher in Belgium (2017: 53\%) than in the other countries. The main level of bargaining is sectoral and the levels of industrial conflict are relatively low, among other things because of the cooperative social partnership approach. There is also a tradition of religiously based organizations. Employee representation is typically organized in a dual system including both union representation and work councils. 
The Nordic countries-Denmark, Finland, Iceland, Norway and Sweden-are in contrast to Central/Eastern Europe rather homogenous in their industrial relations systems (e.g., Jochem 2011; Visser et al. 2009). Their industrial relations regime is labelled organized corporatism, characterized by strong employer organizations and unions negotiating collective agreements with a high degree of autonomy from the state and with high coverage. The national confederations are largely organized on the basis of social class, as opposed to the ideological and religious divisions in some other parts of Europe. The autonomy of bargaining and the strength of unions have created a need for them to take responsibility for the functioning of the labour markets. With the help of state mediation and conflict resolution, the level of open conflict between the partners has been kept relatively low. Despite their autonomy, the Nordic unions have since long comparatively strong influence on government policies, because of their organizational strength and historical connection to social democratic parties and governments. They also have quite well coordinated organizations through their single-channel representation from company to national confederate levels, but with collective bargaining centred at the sectoral level.

In the Southern part of Europe, France, Greece, Italy, Portugal and Spain are said to make up a polarized/state-centred regime of industrial relations (Bieler and Schulten 2008; Visser et al. 2009). This regime is based on traditions of conflict between employer organizations and trade unions. It entails a more fragmented union movement divided according to political and religious differences. Other features are relatively weak coordination between different levels of bargaining and rather low union density. There is a variation in the principal level of bargaining between countries and we find both single- and dual-channel representation. Southern European countries show more of politicized involvement of the social partners and more frequent state intervention into the determination of wages and labour standards compared to the Nordic region and Central/Western Europe. Strikes are seen as an important means of political protest to influence the state to take action.

Western European countries-the United Kingdom and Ireland-are categorized as belonging to a liberal pluralist regime, to which also Malta and Cyprus are sometimes added (Bieler and Schulten 2008; Visser et al. 
2009). This regime is characterized by lower degrees of state intervention in industrial relations and less of legally established standard provisions than the Southern European, Nordic and Central/Eastern European regimes. Unions' involvement in policy-making is more ad hoc in nature. Collective agreement coverage is relatively low, even though union density is moderate compared to European overall levels. Trade union coordination is more fragmented than in the Nordic and Central/Western European regions, which is linked to the fact that collective bargaining is more decentralized, with company bargaining as typical.

\section{Sectoral Comparisons across Europe}

As hinted above, regime typologies can be criticized for hiding some variation between the countries clustered together (Gumbrell-McCormick and Hyman 2013: 8-28; Lehndorff et al. 2017). The Nordic regime appears to be the most homogenous, whereas Central/Eastern Europe is a quite heterogeneous region. Another aspect is the variation in industrial relations within each of the countries. There can actually be more diversity in industrial relations across sectors within a country than within sectors in the EU (Bechter et al. 2012). From this point of view, it has been suggested that it is better to compare sectors than regimes. We may even speak about sectoral regimes of industrial relations in Europe (Bechter and Brandl 2015b).

The basis for a sectoral approach in the study of industrial relations is that industries differ in many ways-for example, in terms of work organization, production processes and market frameworks. The sectoral (economic) context may thus influence industrial relations more strongly than national (political) contexts (Bechter and Brandl 2015b). If also taking into consideration that labour organizations in different sectors may have diverging identities, resources and relations to employers, it is likely that we can uncover effects on the engagement in European union cooperation. Sector differences can also impact on the more specific balance regarding unions' choices of which channels to work through and of what strategies to pursue in relation to EU policies. 
With respect to sectoral differences we should note that some industries, particularly manufacturing, operate on highly integrated product markets with high exposure to international competition. If their work organization enables a high degree of production transferability, the trade unions need to embark on transnational cooperation. More 'sheltered' industries — such as healthcare and education — are less exposed to international competition and have less opportunity for production relocation across borders (Bechter et al. 2012). Trade unions are then under less external pressure to engage in transnational collaboration and have developed it in weaker forms. The opposite applies to unions in sectors under international competitive pressure; they are more likely to be active in cross-border cooperation and lobbying than those in sectors focused more on national markets (Bieler 2005; Gumbrell-McCormick and Hyman 2013: 160).

Some reservations have to be added to this argument. Industries that have undergone liberalization, such as civil aviation and telecommunications, and sectors that in other ways have been heavily affected by EU policies have also had strong motives to collaborate across borders to try to influence these policies (Müller et al. 2010). An example worth mentioning is the construction sector that has been greatly affected by the posting of workers. Moreover, there are significant sectoral differences in terms of union organization and resources. Trade unions in manufacturing usually have a stronger organization and more resources nationally, compared to unions in services and professional occupations.

\section{European-Level Industrial Relations}

The third way to approach industrial relations in Europe is to look at the existence of European-level associations, interactions and institutions, making up a relatively autonomous set-up of industrial relations structures at supranational level (Marginson and Sisson 2004; Smismans 2012). To begin with the collective actors, consisting of employee and employer associations and the state, we find a structure similar to that at national level, with tripartite relations between these actors. There 
are also supranational relations between employers and workers in crosssectoral, sectoral and company-level organs. The European Commission, the European Council and other EU institutions then make up the actors taking the role of the state in the European setting. Social partner organizations exist at both cross-industry and sectoral levels. On the labour side, the main actor is the cross-industry ETUC and its sister organization Eurocadres, which is a joint European association for professionals and managers in both the private and the public sector. The ETUC was established in 1973 from already existing trade union cooperation in the EEC and EFTA countries, aimed at both lobbying and getting access to decision-making structures (Dølvik 1997: 134-150; cf. Degryse and Tilly 2013). There are approximately 90 peak-level confederations as members of the ETUC and, additionally, ten sector-based European Trade Union Federations (ETUFs). Eurocadres was founded in 1993 and has about 60 national trade unions and six of the ETUFs as member organizations. The counterparts at cross-industry level are the employer organizations BusinessEurope (previously called UNICE) with roughly 40 national business federations as affiliates, CEEP representing public sector employers, and SMEunited (previously called UEAPME) with circa 70 national organizations representing small- and mediumsized employers.

Moving on to the institutions and interactions, we find arenas for bipartite negotiations and access points to EU policy-making for both employer organizations and trade unions. These have been developed over a long time and to some extent they mirror at least a minimal set of industrial relations institutions at national level (Rhodes 2015). The European-level social partners have a number of access points to EU policy-making by being invited to consultations in various committees, for example the Economic and Social Committee, the Standing Committee on Employment, the Macroeconomic Dialogue, and the European Semester. However, unions have quite limited power in these, which have been said to be channels more for information and advice than for influencing policy development (Welz 2008: 217-278).

There are also institutionalized arenas for bipartite dialogue between employers and trade unions through the Social Dialogue at cross-industry as well as sectoral levels. The European Social Dialogue (ESD) was 
brought about in the mid-1980s to facilitate collective bargaining and regulation at cross-industry level between the ETUC, on the one hand, and BusinessEurope, CEEP and SMEunited, on the other. The idea was that the social partners should be given possibilities to contribute to European integration and to a strengthening of the EU's social dimension (Tricart 2019). With the institutionalization of the ESD in 1987, the social partners acquired the right of forming binding agreements that could be converted into directives and they thus obtained a function as a corporatist, semi-legislative organ (Welz 2008). During its first decade, the ESD at cross-industry level produced a few agreements that were turned into directives, but not without pressure from the European Commission (Welz 2008: 381-385). A second avenue was also instituted through the right to produce autonomous bipartite agreements to be implemented by the partners themselves rather than through directives. In the late 1990s, with the European Commission taking a step back, the ESD became mainly bipartite and autonomous and its regulatory effect decreased (Welz 2008: 258-340; Rhodes 2015; Prosser 2016).

Table 1.2 gives some examples in which the social partners had an indirect consultative role or direct involvement in producing important regulations - and in the case of autonomous agreements also in implementing them. The information in the table both provides further information on the regulative pillars of European-level institutions and illustrates some important interaction outcomes from these institutions.

\section{Sectoral European-Level Industrial Relations}

Just as at national level, we also have European trade union and employer organizations at sectoral level. On its webpage concerning social dialogue, the European Commission lists 15 sectoral ETUFs. ${ }^{1}$ Like the ETUC, the ETUFs - previously called European Industry Federations (EIFs) - are meta-organizations, that is, they have organizations as members (Ahrne and Brunsson 2008). The ETUF members are trade unions below the peak level, organized from broad sectoral bases. Some of the main ones are listed below: 
- European Federation of Building and Woodworkers (EFBWW)

- European Federation of Food, Agriculture and Tourism trade Unions (EFFAT)

- European Federation of Public Service Unions (EPSU)

- European Trade Union Committee for Education (ETUCE)

- European Transport Workers' Federation (ETF)

- European Trade Union Federation for Services and Communication (UNI-Europa)

- IndustriALL Europe ${ }^{2}$

Table 1.2 Directives and agreements of cross-industry relevance
A) Directives from the ordinary legislative procedure
European Works Councils, 1994 (rev. 2009): Rules for EWCs in companies operating in at least two European Economic Area countries
Posting of workers (PWD), 1996 (rev. 2018): Regulates remuneration for posted workers, long-term posting and more
Working time, 2003: Regulates weekly working time, rest and leave, with a maximum of 48 hours average weekly working time

Services, 2006: Facilitates trade in services between countries. Several sectors exempt

Temporary Agency Work, 2008: Provides workers from employment agencies similar conditions as regular employees

Enforcement of PWD, 2014: Aims at a better application of the PWD

B) Negotiated law (Directives from the ESD)

Parental leave, 1995 (rev. 2009): Gives parents the right to 4 months of leave, of which 1 is non-transferable between parents

Part-time work, 1997: Prohibits discrimination of part-time workers

Fixed-term work, 1999: Prohibits discrimination of temporary employees

C) Autonomous agreements (from the ESD)

Telework, 2002: Regulates teleworkers conditions, health and safety and collective rights

Work-related stress, 2004: Prescribes measures to prevent and manage work-related stress

Harassment and violence, 2007: Prescribes measures to prevent and deal with bullying, sexual harassment and violence

Inclusive labour markets, 2010: Prescribes measures for marginalized and disadvantaged groups in the labour market

Active ageing, 2010: Aims to create good conditions for workers of all ages

Sources European Commission webpage and Social Dialogue texts database 
In addition to these, there are also some sector-narrower ETUFs. The employer side at sectoral level is more fragmented and the European Commission lists more than 60 such meta-organizations. However, these include both cross-national employer associations and organizations that are more of business associations with national members based on industry interest rather than on a status as employers.

Already before the ESD was instituted, some sectors had voluntary social dialogues between the social partners at European level. In 1998, the European Commission wanted to supplement the cross-industry ESD and therefore reorganized the informal sectoral committees into formally recognized and co-funded European Sectoral Social Dialogue (ESSD) committees. These were provided with similar opportunities of producing negotiated law and bipartite agreements as the cross-industry ESD had been given in the 1980s (Degryse 2015; Keller and Weber 2011). Since their establishment, the number of ESSD committees has expanded from around 20 to well over 40. They cover different sectors and from their formation to the present, they have produced over 900 documents co-signed by employers and unions. Yet, only very few of these outcomes are autonomous agreements or negotiated law (Table 1.3). The majority are lobbying statements, procedural documents and soft instruments such as declarations, tools and recommendations that have quite little effect at national level. Some of the last attempts at producing negotiated law from the ESSDs have actually been blocked politically, for example the agreements on health and safety in hairdressing and on information and consultation rights for government employees (Tricart 2019). 
Table 1.3 Directives and agreements of sectoral relevance

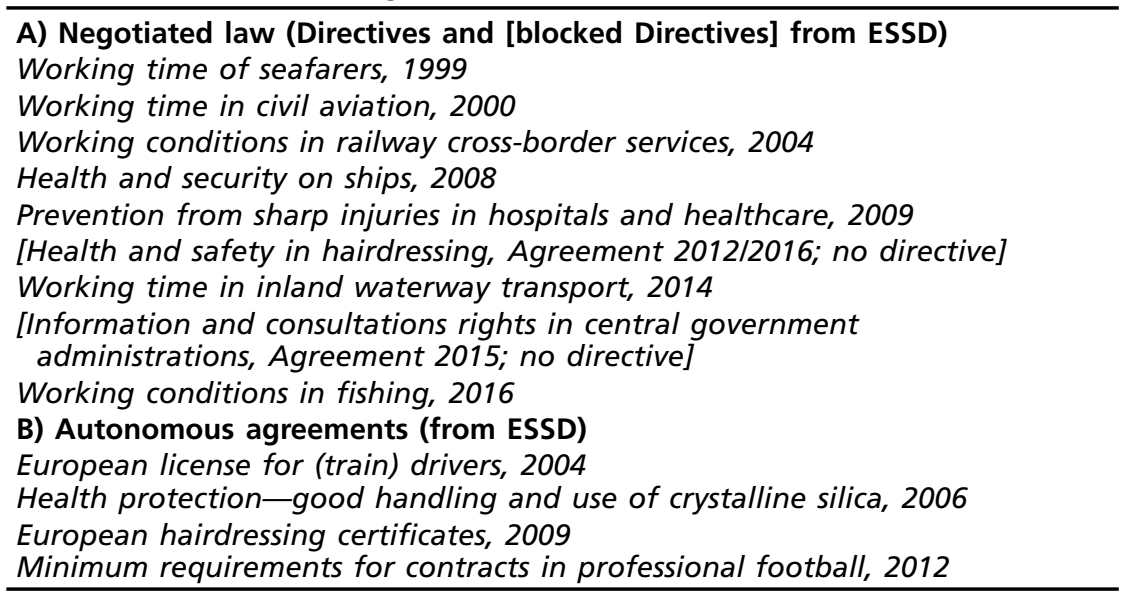

Sources European Commission webpage and Social Dialogue texts database

\section{Data Collection Methods and Empirical Materials}

Empirically, this book is based on data collected during two major research projects performed in the period 2009-2019. The first project, Can Trade Unions within Europe Cooperate?, was headed by Bengt Furåker and was funded by the Swedish Council for Working Life and Social Research (FAS 2008-0246). The second project, called Conditions for and Obstacles to Trade Union Cooperation in Europe. A Comparative Study of Countries and Sectors, was led by Bengt Larsson and received funding from Riksbankens Jubileumsfond (RJ P13-0776:1). Besides ourselves, our research team included Mattias Bengtsson, Kristina Lovén Seldén, Patrik Vulkan and Anton Törnberg.

The data collected in these projects cover two surveys, a total of 46 interviews with 55 trade union officials from different countries, documents of various kinds and data from existing databases. It should also be mentioned that one of the members of our research team was allowed to participate in the ETUC Executive Committee's meetings during a period and could thus make direct observations. We begin by presenting 
the surveys and the interviews and end by saying a few words about the documents and databases used.

\section{Quantitative Materials}

In both surveys, the aim was to study trade union positions, activities and strategies, that is, the focus was on the organizational and not the individual level. Since we only requested one questionnaire per union, we targeted top-level representatives who could legitimately respond for the whole organization. A majority of the respondents were secretariesgeneral, presidents or vice presidents, and the rest of the respondents had positions like international secretaries or other high-level officials. The surveys were translated into several languages, and we used a mixed-mode approach to improve the response rates. The first two waves of send-outs were web-based and a third wave was postal (Fan and Yan 2010).

Survey 1 was distributed in 2010-2011 to all member organizations of the ETUC - that is, the 85 national confederations and the 12 EIFs (ETUFs) which were ETUC members at the time of the investigation. Moreover, we included 499 trade unions below the peak level in 14 European countries (Austria, Belgium, Denmark, Finland, France, Germany, Iceland, Ireland, Norway, Poland, Spain, Sweden, Switzerland and the United Kingdom). The selection of unions in these countries was grounded on an ambition to target unions with approximately 10,000 members or more. The total response rate was $42 \%$ (Table 1.4 ), but if

Table 1.4 Information on survey 1 by region, 2010-2011

\begin{tabular}{lcc}
\hline \multicolumn{1}{c}{ Region } & $\begin{array}{l}\text { Number of answers } \\
\text { (response rates) }\end{array}$ & $\begin{array}{l}\text { Number of unions in } \\
\text { send-out }\end{array}$ \\
\hline Central/Eastern Europe & $31(20 \%)$ & 157 \\
Central/Western Europe & $46(49 \%)$ & 93 \\
Nordic region & $102(70 \%)$ & 146 \\
Southern Europe & $35(26 \%)$ & 137 \\
Western Europe & $27(53 \%)$ & 51 \\
EIFs/ETUFs & $9(75 \%)$ & 12 \\
Total & $250(42 \%)$ & 596 \\
\hline
\end{tabular}

ancluding Cyprus and Malta (for details, see Larsson 2012) 
not counting France and Poland in which we had difficulties in selecting unions with at least 10,000 members-because of the fragmented system with a large number of small unions - the response rate was over $70 \%$. Besides some background matters regarding the size of union and who was responding, survey 1 contained general questions about union cooperation and two sets of questions specifically about wage and working time issues.

Survey 2 was distributed in 2015-2016 to 602 trade unions in 36 European countries. We directed it to unions in six main sectors according to an established typology (Crouch 1999): mining (extractive), metal, construction (productive/transformative), transport (distributive), healthcare, and banking and finance (public and private services). This strategic selection was designed to achieve large variation in aspects identified as important for sectoral union cooperation: production processes, work organization, possibilities for relocation and exposure to international competition. The overall response rate was 37\%, with a total of 221 answers (Table 1.5). The sectors of mining and metals are merged in our analyses, because many unions organized employees in both sectors. Furthermore, an extra category of multisectoral unions was created to gather unions organizing employees in more than one of the sectors. In addition to asking about size and sector and who the respondent was, survey 2 enclosed wide-ranging questions about union cooperation and a set of questions specifically about wage issues.

Given the response rates on both surveys, a general note of caution as regards the results is required. From our attempts to recruit interviewees

Table 1.5 Information on survey 2 by region, 2015-2016

\begin{tabular}{lcc}
\hline \multicolumn{1}{c}{ Region } & $\begin{array}{l}\text { Number of answers } \\
\text { (response rates) }\end{array}$ & $\begin{array}{l}\text { Number of unions in } \\
\text { send-out }\end{array}$ \\
\hline Central/Eastern Europe & $69(27 \%)$ & 255 \\
Central/Western Europe & $35(39 \%)$ & 89 \\
Nordic region & $73(62 \%)$ & 117 \\
Southern Europe & $35(32 \%)$ & 110 \\
Western Europe $^{\mathrm{a}}$ & $9(18 \%)$ & 51 \\
Total & $221(37 \%)$ & 602 \\
\hline
\end{tabular}

ancluding Cyprus and Malta (for details, see Larsson [2012] and Vulkan and Larsson [2019], online supplementary material) 
(see below), we got the impression that the lesser the trade unions participated in transnational cooperation, the less inclined they were to take part in this research. Thus, both the survey and the interviews may be biased in the sense that the level of cross-border collaboration shown is higher than it is among the non-responding unions. Another problem is the large differences in response rates across regions.

\section{Qualitative Materials}

In total, we conducted 46 interviews with 55 top-level or senior officials in the two projects. The interviews were semi-structured and lasted around 1-2 hours. They were done in person, via Skype or telephone and in one case via e-mail. The conversations were recorded and transcribed verbatim-except for two for which only a summary was written, because the respondents did not want to be recorded or quoted directly. We coded the interviews thematically using software for qualitative analysis.

The first interview study included 17 interviews conducted in 20112012 in connection with the first survey. These had a thematic orientation on wage issues, with some focus on minimum wages. Respondents were chosen to represent different national views on the main topics: Belgium (3 interviews), Germany (5), Latvia (1), Spain (3) and Sweden (5). Ten of the interviewees represented cross-sectoral confederations and seven represented sectoral or multisectoral trade unions (cf. Furåker and Lovén Seldén 2013: 510-511).

The second interview study was done during 2015-2016, close to the second survey. We conducted 29 interviews, with unions in healthcare (8), construction (5), metal (5), banking and finance (5), and transport (3). From recommendations by contacts in Central/Eastern Europe, we also included one union confederation and one union each in education and energy in that region. Our selection aimed to achieve a variation in sectors and regions corresponding to the survey. The Nordic countries were represented by Sweden (7) and a joint Nordic labour organization (1); Central/Western Europe by Germany (4); Southern Europe by Italy (5); Central/Eastern Europe by the Czech Republic (3), Hungary (3), 
Latvia (2) and Lithuania (1); and Western Europe by the United Kingdom (3) (cf. Larsson and Törnberg 2019: 7).

Besides the interviews, we also utilized documents and data from other sources: We made use of European Commission documents, webpages and the Social Dialogue Texts Database to get information on social dialogues and their outcomes. Another source of information was the ICTWSS Database on Institutional Characteristics of Trade Unions, Wage Setting, State Intervention and Social Pacts in 55 countries between 1960 and 2017 (Visser 2019). We were also given access to certain data from the ETUC, of which we primarily used the minutes of the ETUC Executive Committee meetings (Furåker and Lovén Seldén 2016). It should be repeated that one member of the research team had the possibility of attending some of these meetings.

\section{Notes}

1. https://ec.europa.eu/social/main.jsp?catId=329\&langId=en (accessed October 8, 2019).

2. IndustriALL was established through a 2012 merger of the European Metalworkers' Federation (EMF), the European Mine, Chemical and Energy Workers Federation (EMCEF) and the European Trade Union Committee: Textile, Clothing and Leather (ETUC-TCL).

\section{References}

Ahrne, G., and N. Brunsson. 2008. Meta-organizations. Cheltenham: Edward Elgar.

Baccaro, L., and C. Howell. 2017. Trajectories of Neoliberal Transformation: European Industrial Relations Since the 1970s. Cambridge: Cambridge University Press.

Bamber, G.J., R.D. Lansbury, N. Wailes, and C.F. Wright (eds.). 2016. International and Comparative Employment Relations, 6th ed. London: Sage. 
Bechter, B., and B. Brandl. 2015a. Developments in European Industrial Relations. In Industrial Relations in Europe 2014, 17-40. Brussels: European Commission.

Bechter, B., and B. Brandl. 2015b. Measurement and Analysis of Industrial Relations Aggregates: What Is the Relevant Unit of Analysis in Comparative Research? European Political Science 14 (4): 422-438.

Bechter, B., B. Brandl, and G. Meardi. 2012. Sectors or Countries? Typologies and Levels of Analysis in Comparative Industrial Relations. European Journal of Industrial Relations 18 (3): 185-202.

Bieler, A. 2005. European Integration and the Transnational Restructuring of Social Relations: The Emergence of Labour as a Regional Actor? Journal of Common Market Studies 43 (3): 461-484.

Bieler, A., and T. Schulten. 2008. European Integration: A Strategic Level for Trade Union Resistance to Neoliberal Restructuring and for the Promotion of Political Alternatives? In Labour and the Challenges of GlobalizationWhat Prospects for Transnational Solidarity? ed. A. Bieler, I. Lindberg, and D. Pillay, 231-247. London: Pluto Press.

Brown, G.W., I. McLean, and A. McMillan. 2018. Industrial Relations. In A Concise Oxford Dictionary of Politics and International Relations. Oxford: Oxford University Press.

Bücker, A., and W. Warneck (eds.). 2010. Viking-Laval-Rüffert: Consequences and Policy Perspectives. Brussels: ETUI.

Crouch, C. 1999. Social Change in Western Europe. Oxford: Oxford University Press.

Degryse, C. 2015. The European Sectoral Social Dialogue: An Uneven Record of Achievement?. Brussels: ETUI.

Degryse, C., and P. Tilly. 2013. 1973-2013: 40 Years of History of the European Trade Union Confederation. Brussels: ETUI.

Dølvik, J.E. 1997. Redrawing Boundaries of Solidarity? ETUC, Social Dialogue and the Europeanization of Trade Unions in the 1990s. Oslo: Fafo.

Dunlop, J.T. 1958. Industrial Relations Systems. New York: Holt.

Erne, R. 2008. European Unions: Labor's Quest for a Transnational Democracy. Ithaca: Cornell University Press.

Eurofound. 2017. Mapping Varieties of Industrial Relations: Eurofound's Analytical Framework Applied. Luxembourg: Publications Office of the European Union.

European Commission. 2016. A New Start for Social Dialogue. Luxembourg: Publications Office of the European Union. 
European Commission. 2017. European Pillar of Social Rights. Luxembourg: Publications Office of the European Union.

Fan, W., and Z. Yan. 2010. Factors Affecting Response Rates of the Web Survey: A Systematic Review. Computers in Human Behavior 26 (2): 132-139.

Furåker, B., and K. Lovén Seldén. 2013. Trade Union Cooperation on Statutory Minimum Wages? A Study of European Trade Union Positions. Transfer: European Review of Labour and Research 19 (4): 507-520.

Furåker, B., and K. Lovén Seldén. 2016. Patterns of Speech Activity at ETUC Executive Committee Meetings, 2005-2012. European Journal of Industrial Relations 22 (1): 57-71.

Gajewska, K. 2009. Transnational Labour Solidarity: Mechanisms of Commitment to Cooperation within the European Trade Union Movement. London: Routledge.

Godard, J. 2004. The New Institutionalism, Capitalist Diversity, and Industrial Relations. In Theoretical Perspectives on Work and the Employment Relationship, ed. B.E. Kaufman, 229-264. Champaign, IL: Industrial Relations Research Association.

Gumbrell-McCormick, R., and R. Hyman. 2013. Trade Unions in Western Europe: Hard Times, Hard Choices. Oxford: Oxford University Press.

Hann, D., M. Hauptmeier, and J. Waddington. 2017. European Works Councils After Two Decades. European Journal of Industrial Relations 23 (3): 209224.

Henning, K. 2015. Trade Unions and Industrial Relations in the EU Member States of Eastern Enlargement. In Interest Representation and Europeanization of Trade Unions from EU Member States of the Eastern Enlargement, ed. C. Landgraf and H. Pleines, 53-71. Stuttgart: Ibidem.

Hyman, R. 1994. Industrial Relations in Western Europe: An Era of Ambiguity? Industrial Relations 33 (1): 1-24.

Hyman, R. 2001a. Trade Union Research and Cross-National Comparison. European Journal of Industrial Relations 7 (2): 203-232.

Hyman, R. 2001b. Understanding European Trade Unionism: Between Market, Class and Society. London: Sage.

Jochem, S. 2011. Nordic Employment Policies-Change and Continuity before and during the Financial Crisis. Social Policy \& Administration 45 (11): 131-145.

Keller, B., and S. Weber. 2011. Sectoral Social Dialogue at EU Level: Problems and Prospects of Implementation. European Journal of Industrial Relations 17 (3): $227-243$. 
Kelly, J. 2015. Trade Union Membership and Power in Comparative Perspective. The Economic and Labour Relations Review 26 (4): 526-544.

Larsson, B. 2012. Obstacles to Transnational Trade Union Cooperation in Europe-Results from a European Survey. Industrial Relations Journal 43 (2): 152-170.

Larsson, B., and A. Törnberg. 2019. Sectoral Networks of Transnational Trade Union Cooperation in Europe. Economic and Industrial Democracy. Published online ahead of print. https://doi.org/10.1177/0143831x19853871.

Lehndorff, S., H. Dribbusch, and T. Schulten. 2017. European Trade Unions in a Time of Crises-An Overview. In Rough Waters: European Trade Unions in a Time of Crises, ed. S. Lehndorff, H. Dribbusch, and T. Schulten, 7-35. ETUI: Brussels.

Marginson, P. 2015. Coordinated Bargaining in Europe: From Incremental Corrosion to Frontal Assault? European Journal of Industrial Relations 21 (2): 97-114.

Marginson, P., and K. Sisson. 2004. European Integration and Industrial Relations: Multi-Level Governance in the Making. Basingstoke: Palgrave Macmillan.

Müller, T., H.-W. Platzer, and S. Rüb. 2010. Transnational Company Policy and Coordination of Collective Bargaining-New Challenges and Roles for European Industry Federations. Transfer: European Review of Labour and Research 16 (4): 509-524.

Perin, E., and E. Léonard. 2011. European Sectoral Social Dialogue and National Social Partners. Transfer: European Review of Labour and Research 17 (2): 159-168.

Prosser, T. 2016. Economic Union without Social Union: The Strange Case of the European Social Dialogue. Journal of European Social Policy 26 (5): 460-472.

Rhodes, M. 2015. Employment Policy: Between Efficacy and Experimentation. In Policy Making in the European Union, ed. H. Wallace, M.A. Pollack, and A.R. Young, 294-317. Oxford: Oxford University Press.

Scharpf, F.W. 1996. Negative and Positive Integration in the Political Economy of European Welfare States. In Governance in the European Union, ed. G. Marks, F.W. Scharpf, P.C. Schmitter, and W. Streeck, 15-39. London: Sage. Seeliger, M. 2019. Trade Unions in the Course of European Integration: The Social Construction of Organized Interests. London: Routledge.

Smismans, S. (ed.). 2012. The European Union and Industrial Relations: New Procedures, New Contexts. Manchester: Manchester University Press. 
Traxler, F. 1998. Collective Bargaining in the OECD: Developments, Preconditions and Effects. European Journal of Industrial Relations 4 (2): 207-226. Tricart, J.P. 2019. Legislative Implementation of European Social Partner Agreements: Challenges and Debates. Brussels: ETUI.

Visser, J. 2019. ICTWSS Database. Version 6.0. Amsterdam: Amsterdam Institute for Advanced Labour Studies (AIAS), University of Amsterdam.

Visser, J., M. Beentjes, M. van Gerven, and V. Di Stasio. 2009. The Quality of Industrial Relations and the Lisbon Strategy. In Industrial Relations in Europe 2008, 45-72. Luxembourg: Publications Office of the European Union.

Vulkan, P., and B. Larsson. 2019. Patterns of Transnational Trade Union Cooperation in Europe: The Effects of Regimes, Sectors and Resources. European Journal of Industrial Relations 25 (2): 147-162.

Webb, S., and B. Webb. 1894. The History of Trade Unionism. London: Longmans, Green, and Co.

Welz, C. 2008. The European Social Dialogue Under Articles 138 and 139 of the EC Treaty: Actors, Processes, Outcomes. Alphen aan den Rijn: Kluwer.

Whittall, M., H. Knudsen, and F. Huijgen (eds.). 2007. Towards a European Labour Identity: The Case of the European Works Council. London: Routledge.

Open Access This chapter is licensed under the terms of the Creative Commons Attribution 4.0 International License (http://creativecommons.org/ licenses/by/4.0/), which permits use, sharing, adaptation, distribution and reproduction in any medium or format, as long as you give appropriate credit to the original author(s) and the source, provide a link to the Creative Commons license and indicate if changes were made.

The images or other third party material in this chapter are included in the chapter's Creative Commons license, unless indicated otherwise in a credit line to the material. If material is not included in the chapter's Creative Commons license and your intended use is not permitted by statutory regulation or exceeds the permitted use, you will need to obtain permission directly from the copyright holder.

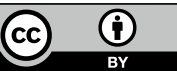

